\title{
PEDAGOGY
}

\section{ІС-ӘРЕКЕТТІ ЗЕРТТЕУ: МЕКТЕП БІТІРУШІЛЕРДІ ҚОРЫТЫНДЫ АТТЕСТАТТАУҒА ДАЙЫНДАУ ҮРДІСІНДЕ ЕМТИХАН НӘТИЖЕЛЕРІНІҢ ТАБЫСТЫ БОЛУЫНА ӘСЕР ЕТУШІ НЕГІЗГІ ФАКТОРЛАРДЫ АЙҚЫНДАУ}

\author{
Кариева Г. Ж. \\ Орал қ̧аласындавы физика-математика бавытындавы Назарбаев Зияткерлік мектебінің \\ математика пәнінің мұвалімі, Қазақ̆стан
}

DOI: https://doi.org/10.31435/rsglobal_ws/30062019/6567

\section{ARTICLE INFO}

Received: 20 April 2019

Accepted: 18 June 2019

Published: 30 June 2019

\section{KEYWORDS}

learning process, independent work, self-study skill, individual quality. \begin{abstract}
When preparing graduates for final certification, special attention should be paid to determining the key factors affecting the exam results in external summative assessment. The purpose of the study is to highlight the main factors, such as the individual quality of students and the level of independent work skills that affect the successful outcome of the exams. Methodology: a questionnaire survey was carried out and a correlation analysis of the results was presented. The mathematical statistics methods in Excel application were used for processing the survey data.

Research methods: data collection, statistical mathematical data processing, analysis of the results, and interviews

The results of the study: In the process of preparing the final certification of graduates, the success of the exam results is closely related to the level of students' independent work skills. and self-education. In turn, the readiness for self-education cannot be carried out without independent work, the attitude to which was determined as a result of the conducted research.

Outcome of the study: Successful completion of school exams is closely related to the ability to work independently. Therefore, to increase the academic knowledge of students, it is necessary to focus on the ability of students to work independently in the learning process and to develop effective teaching methods for self-improvement.
\end{abstract}

Citation: Кариева Г. Ж. (2019) Ic-Әрекетті Зерттеу: Мектеп Бітірушілерді Қорытынды Аттестаттауға Дайындау Үрдісінде Емтихан Нәтижелерінің Табысты Болуына Әсер Етуші Негізгі Факторларды Айқындау. World Science. 6(46), Vol.2. doi: 10.31435/rsglobal_ws/30062019/6567

Copyright: (ㄷ 2019 Кариева Г. Ж. This is an open-access article distributed under the terms of the Creative Commons Attribution License (CC BY). The use, distribution or reproduction in other forums is permitted, provided the original author(s) or licensor are credited and that the original publication in this journal is cited, in accordance with accepted academic practice. No use, distribution or reproduction is permitted which does not comply with these terms.

I. Kiрiспе. «Ғасыр мақсаты - қоғамның нарықтық қарым-қатынасқа көшу кезінде саясиэкономикалық және рухани дағдарыстарды жеңіп шыға алатын, ізгіленген XXI ғасырды құрушы, іскер, өмірге икемді, жан-жақты мәдениетті жеке тұлғаны қалыптастыруға қол жеткізу» [1]. Осы орайда, ақыл-ойы жетілген, жан-жақты дамыған, еңбек етуге қабілетті, өз тағдырларын өздері шеше алатын, өз бетінше білімін толықтыру және өздігінен кәсіби шеберлігін арттыру мүмкіндігі бар болашақ мамандарды даярлау Назарбаев Зияткерлік мектептерінің де күн тәртібіндегі мәселе екендігі даусыз. Осындай үлкен жауапкершілік арқалаған мектеп түлектері 12 сыныпты аяқтаған соң Cambridge Primary stage, IGCSE, AS-level және A-level және басқа да халықаралық стандарттарға сәйкес келетін сыртқы жиынтық бағалаудан өтеді. [2,23 бет] 
Оқыту үрдісіндегі осындай өзекті мәселелерді шешу кезеңдерінде, яғни окушыларды емтиханға тиімді дайындауға ықпалдасатын оқу әдістемелік кешенді әзірлеу барысында мұғалімдердің алдында емтихан нәтижелеріне әсер етуші негізгі факторларды айқындаудың қажеттілігі туындайды.

Зерттеу мақсаты: емтихан нәтижелеріне әсер етуші негізгі факторлар ретінде оқушылардың жеке тұлғалық қасиеттері және өзбетімен жұмыс дағдыларының қалыптасу деңгейі мен емтихан нәтижелерінің арасындағы байланысты айқындау

Проблема: Окушылардың қорытынды емтиханға дайындалу барысында өз бетімен оқу дағдылары деңгейінің төмен болуының байқау сынықтарындағы нәтижелеріне кері әсері

Болжам:

- Окушылардың жеке тұлғалық қасиеттері мен қорытынды емтихан нәтижесінің арасындағы байланыс бар және оң болуы мүмкін.

- Өзбетімен оқу дағдысы деңгейі мен қорытынды емтихан нәтижесінің арасындағы байланыс маңызды көрініс табуы мүмкін.

- Өзбетімен оқуға жұмсалған уақыт мөлшері мен қорытынды емтихан нәтижесінің арасындағы байланыс көрініс табуы мүмкін.

Міндеттері:

- Қорытынды емтихан нәтижелеріне әсер етуші жиынтық факторларды анықтау және таңдама жасау;

- Өзбетімен оқуды жетілдіру үшін қажетті жеке тұлғалық қасиеттердің әсерін зерттеу;

- Математикадан өзбетімен окуға ықпал ететін оқыту әдістерін таңдау және қолдану;

- Зерттеу нәтижелеріне талдау жүргізу, қорыту

Зерттеу әдістемесі:

Деректер жинау, деректерді статистикалық математикалық өңдеу, алынған нәтижелерді талдау, сұхбат.

\section{II. Эксперимент жүргізу барысы.}

Бұл іс-әрекетті зерттеу жұмысында мектеп оқушыларының өзбетімен оқу барысы мен тәжірибелері қарастырылды және Орал қаласындағы физика-математикалық бағыттағы Назарбаев Зияткерлік мектебінің шығармашылық топ жұмысының жоспары бойынша 2019 жылдың қаңтар айы мен мамыр айы аралығында жүргізілді. Ғылыми әдістемелік ресурстар және басқа да зерттеу мақалаларымен танысу арқылы оқушылардың өзбетімен жұмысын дамытуда түрлі стратегиялар қолдану қажеттілігі анықталды.

Әдебиет көздерінде оқушының өзбетімен жұмысын тиімді ұйымдастыруға қатысты жақын ойлар берілген. Мысалы: Лукас «Өзбетімен жұмысты оқушылардың ісәрекетті жоспарлай отырып оны жүзеге асыруда мониторинг пен бағалауды қолдану арқылы өзінің оқу үрдісін қадағалауы деп анықтайды» Авторлар еңбектерінде [3],[5]тақырыпқа қатысты ойлары мен идеялары жұмыс жоспарын құруда пайдалы болды.

Оқушылардың өзбетімен оқу үдерісін зерделей отырып өзбетімен жұмыс бойынша тәжірибені жетілдіру және зерттеу нәтижесін басқа пән бірлестіктеріне тарату үшін іс әркетті зерттеу кезеңдері айқындалды:

- Ғылыми әдістемелік ресурстарға шолу және талдау

- Сауалнама жүргізу

- Іс-тәжірибедегі зерттеуді жүргізу, кері байланыс беру

- Іс-тәжірибедегі зерттеу нәтижесін қорытындылау, түйіндеу

Экспериментке 12а,в сыныптарының 22 окушысы өз келісімдері бойынша қатысып, өз үлестерін қосты. Зерттеуге алынған оқушыларға сауалнама, интервьюмен бірге өзбетімен жұмыс барысын бақылау және оған жұмсаған уақытын тіркеу мақсатында «күнделік жүргізу» әдісі қолданылды.

Күнделікке оқушылар өздерінің қиындық тудырған тақырыптарын, өз бетімен жұмыстануға жұмсаған уақыттарын тіркеп отырды.

Кесте 1. Өзбетімен жұмыс күнделігі

\begin{tabular}{|l|l|l|l|l|l|}
\hline № & Тақырып & $\begin{array}{l}\text { Жақсы } \\
\text { меңгердім }\end{array}$ & $\begin{array}{l}\text { Қайталауды } \\
\text { қажет етеді }\end{array}$ & $\begin{array}{l}\text { Уақыты } \\
\text { туралы белгі }\end{array}$ \\
\hline 1 & & & & & \\
\hline
\end{tabular}


Сондай-ақ, оқушыларға өзбетімен жұмыстануға арналған кесте құрылып, сол қосымша сабақтар кезінде оларға кері байланыс беріліп отырылды және байқау сынақтары тапсырмалары арқылы мониторинг жүргізілді, олардың өз жетістіктерін өздері бақылап, қадағалауларына ыңғайлы ахуал тудырылды.

«Күнделік жүргізу» төмендегідей жоспармен жүзеге асырылып, оның жүзеге асырылу

барысы бақылауға алынды:

1. Окушыларды журналмен жұмыс барысын таныстыру

2. Сауалнама жүргізу

3. Журналмен жұмыс барысын қадағалау

4. Мәліметтерді жинақтау

5. Окушылармен сұхбат алу

6. Алынған нәтижелерді талдау

7. Қорытынды

Кесте 2. «Күнделік жүргізу» барысын қадағалау

\begin{tabular}{|c|c|c|c|}
\hline & Іс-шаралар & Уақыты & Рефлексия \\
\hline 1 & $\begin{array}{l}\text { Оқушыларды өзбетімен жұмыс } \\
\text { журналымен таныстыру: } \\
\text { Мақсаты: 12а,в сынып } \\
\text { оқушыларының қорытынды } \\
\text { емтиханға даярлау барысында } \\
\text { интернет сайттарындағы емтихан } \\
\text { тапсырмаларымен өзбетімен } \\
\text { жұмыстануын жүзеге асыру; }\end{array}$ & 11.01 .19 & $\begin{array}{l}\text { Оқушылармен қорытынды емтиханға дайындық } \\
\text { барысындағы байқау сынақтары қорытындысы } \\
\text { бойынша әр оқушының біліміндегі } \\
\text { олқылықтарды өзбетімен анықтай отырып, } \\
\text { алдағы уақытта өзбетімен жетілдіруді қажет } \\
\text { ететін тақырыптарды анықтау және жоспар құру } \\
\text { арқылы кестені толтыру ұсынылды. }\end{array}$ \\
\hline 2 & $\begin{array}{l}\text { Сауалнама жүргізу } \\
\text { Мақсаты: өзбетімен оқуды жетілдіру } \\
\text { үшін қажетті жеке тұлғалық } \\
\text { қасиеттердің әсерін зерттеу }\end{array}$ & 28.01 .19 & $\begin{array}{l}\text { Сауалнама оқушыларға өздеріне сын көзбен } \\
\text { қарап, өз-өздерін бағалауға мүмкіндік берді. } \\
\text { Әр оқушының } 18 \text { түрлі қасиеті бойынша орта } \\
\text { шамасы анықталды. }\end{array}$ \\
\hline 3 & $\begin{array}{l}\text { Әр оқушының жеке өзбетімен жұмыс } \\
\text { жоспарын жасау } \\
\text { Мақсаты: тақырыптар бойынша өз } \\
\text { білімдеріндегі олқылықтарды түзету }\end{array}$ & 18.01 .19 & $\begin{array}{l}\text { Әр оқушыға өз қажеттіліктеріне қарай жеке } \\
\text { жұмыстануына қолайлы жағдай туды және } \\
\text { олар мұғалімнен жеке кері байланыс алуға } \\
\text { мүмкіндік алды. }\end{array}$ \\
\hline 4 & $\begin{array}{l}\text { Оқушылардың өзбетімен жұмысын } \\
\text { журнал арқылы қадағалау, бақылау } \\
\text { жүргізу }\end{array}$ & $\begin{array}{l}\text { сәуір } \\
\text { мамыр }\end{array}$ & $\begin{array}{l}\text { Оқушылардың (25\% )-өзбетімен жұмысқа } \\
\text { ынталана қоймағандықтары байқалды. (45\%)- } \\
\text { жоғары белсенділіктерін көрсетті. }\end{array}$ \\
\hline 5 & $\begin{array}{l}\text { Оқушылардың өз-өздерін тәртіпке } \\
\text { келтіру барысын бақылау }\end{array}$ & $\begin{array}{l}\text { сәуір } \\
\text { мамыр }\end{array}$ & $\begin{array}{l}\text { Окушылардың (40\%)- да өзбетімен жұмыс } \\
\text { дағдысының артқандығы байқалды. }\end{array}$ \\
\hline 6 & Жекелеген оқушылармен сұхбаттасу & $\begin{array}{l}\text { сәуір } \\
\text { мамыр }\end{array}$ & $\begin{array}{l}\text { Өзбетімен жұмыста қиналған оқушылармен } \\
\text { жүргізілген сұхбат олардың өзбетімен } \\
\text { жұмысқа дайын еместіктерін көрсетті.Олар өз } \\
\text { бетімен жұмыс кезінде алаңдап } \\
\text { кететіндіктерін, уақыттарын текке } \\
\text { өткізетіндерін, үнемі мұғалім көмегіне } \\
\text { сүйенгенді қалайтындықтарын білдірді. Кері } \\
\text { байланыс беріліп, жеке көмек беріліп отырды. }\end{array}$ \\
\hline 7 & $\begin{array}{l}\text { Өзін-өзі тәртіпке келтірудің } \\
\text { өзбетімен жұмыстану дағдысының } \\
\text { дамуына әсерін бақылау }\end{array}$ & $\begin{array}{l}\text { сәуір } \\
\text { мамыр }\end{array}$ & $\begin{array}{l}\text { Өзбетімен жұмыс дағдысын жақсартқан } \\
\text { оқушылардың байқау сынақтарындағы } \\
\text { нәтижелері көтеріле бастады. }\end{array}$ \\
\hline 8 & $\begin{array}{l}\text { Өзбетімен жұмыстың оқушылардың } \\
\text { байқау сынақтарындағы } \\
\text { көрсеткіштеріне әсерін бақылау, } \\
\text { нәтижелерді талдау }\end{array}$ & мамыр & $\begin{array}{l}\text { Қорытынды аттестаттау нәтижесі бойынша } \\
\text { оқушылардың білім сапасы 68\% пайызды } \\
\text { көрсетті. Бұл өзбетімен жұмыс дағдысын } \\
\text { арттырудың емтихан нәтижесіне әсер етуші } \\
\text { фактор болуы мүмкін деген болжамды } \\
\text { растайды. }\end{array}$ \\
\hline
\end{tabular}

Емтихан нәтижелеріне әсер етуші келесі фактор ретінде оқушылардың жеке тұлғалық қасиеттерін зерттеу мақсатында анкета құрастырылып, оқушының жеке тұлғалық қасиеттері төмендегідей кесте бойынша есепке алынды және орта мәні шығарылды. 
Кесте 3. Сауалнама

\begin{tabular}{|l|l|l|}
\hline Мақсат қою дағдысы: & $\begin{array}{l}\text { Өз қызметін жоспарлау мен реттеу } \\
\text { дағдысы: }\end{array}$ & Өз-өзін бақылай алу дағдысы: \\
\hline 1.Мақсат қою & 8.Ұзақ уақыт жұмыс жасай алуы & 17.Эмоциялық тұрақтылық \\
\hline 2.Ерік-жігері & 9.Жинақылық & 18.Өз-өзіне талап қоя білу \\
\hline 3.Алға ұмтылысы & 10.Тыңдай білу & \\
\hline 4.Табандылық & 11.Белсенділік & \\
\hline 5.Шешім қабылдауда нақтылық & 12.Жинақылық & \\
\hline 6.Саналылық & 13.Еңбекқорлық & \\
\hline 7.Тиімді жұмыстану & 14.Шыдамдылық & \\
\hline & 15.Практикада жүзеге асыру & \\
\hline & 16.Тұрақтылық & \\
\hline
\end{tabular}

Эксперимент соңында оқушылардан алынған сұхбат үнтаспаға жазылып, кейін сараптама жасалды:

Кесте 4. Окушылармен жүргізілген сұхбат

\begin{tabular}{|c|c|c|c|}
\hline № & Сұрақ & \multicolumn{2}{|c|}{ Окушы жауаптары(өз қалпында жазылды) } \\
\hline \multirow[t]{2}{*}{1} & \multirow{2}{*}{$\begin{array}{l}\text { Жаңа тақырыпты } \\
\text { өзбетімен меңгерудің } \\
\text { қандай ұтымды және } \\
\text { қолайсыз тұстары бар деп } \\
\text { ойлайсыз? }\end{array}$} & Ұтымды тұстары & Қолайсыз жақтары \\
\hline & & 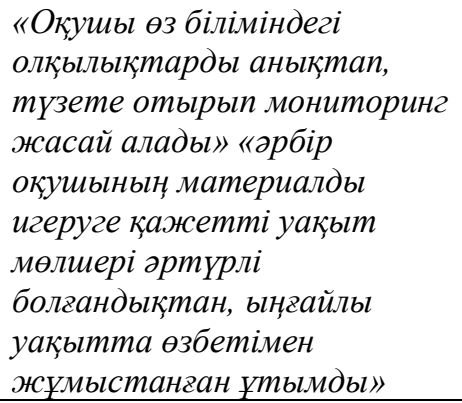 & $\begin{array}{l}\text { «ейбір тақырыптар ауқымдыл } \\
\text { болвандықтан, түйінді мәселелерді } \\
\text { оқушы өзбетімен таба алмауы } \\
\text { мүмкін» } \\
\text { «өзбетімен түсініксіз сұрақтарын } \\
\text { интернет арқылы іздестіру } \\
\text { барысында көп уақытытын текке өткізіп } \\
\text { алуы мүмкін» }\end{array}$ \\
\hline 2 & $\begin{array}{l}\text { Өз бетімен оқу барысын } \\
\text { тексеру қажет пе? } \\
\text { Тексерудің қандай } \\
\text { түрлерін қолданған } \\
\text { тиімді? }\end{array}$ & \multicolumn{2}{|c|}{$\begin{array}{l}\text { «Тексеру оқушыларва кері байланыс алуына сол арқылы білімдеріндегі } \\
\text { олқылықтарды түзетуге мүмкіндік береді.» «Тексерудің } \\
\text { бақылау,байқау сынақтары, ойын түрінде болваны дұрыс.» «Катемен } \\
\text { жұмыс жасау» мен оқушылардың бір-бірін дескриптор бойынша } \\
\text { тексеру де тиімді деп ойлаймын» }\end{array}$} \\
\hline 3 & $\begin{array}{l}\text { Өз бетімен оқуда } \\
\text { «Күнделік жүргізу» } \\
\text { әдісінің тиімді және } \\
\text { тиімсіз тұстары қандай } \\
\text { болды? }\end{array}$ & \multicolumn{2}{|c|}{$\begin{array}{l}\text { «Кнделік жүргізу- окушылардың тақырыптар бойынша өз } \\
\text { білімдеріне мониторинг жасаува, өз бетімен окува жұмсаван } \\
\text { уақылттарын есепке алып отырува, дер кезінде кері байланыс алува } \\
\text { ықпал етеді» } \\
\text { «Күнделік барлық сыныпқа біреу емес, әр окушының өз жеке күнделігін } \\
\text { жүргізгені дұрыс болар еді, өйткені үйдегі өз бетімен жасалган } \\
\text { жұмыстар кейде тіркелмей қалып отыруы мүмкін» }\end{array}$} \\
\hline 4 & $\begin{array}{l}\text { Өз бетімен жұмыс } \\
\text { жасауда қиналатын } \\
\text { оқушыларға қандай } \\
\text { қолдау керек деп } \\
\text { ойлайсыз? }\end{array}$ & \multicolumn{2}{|c|}{ 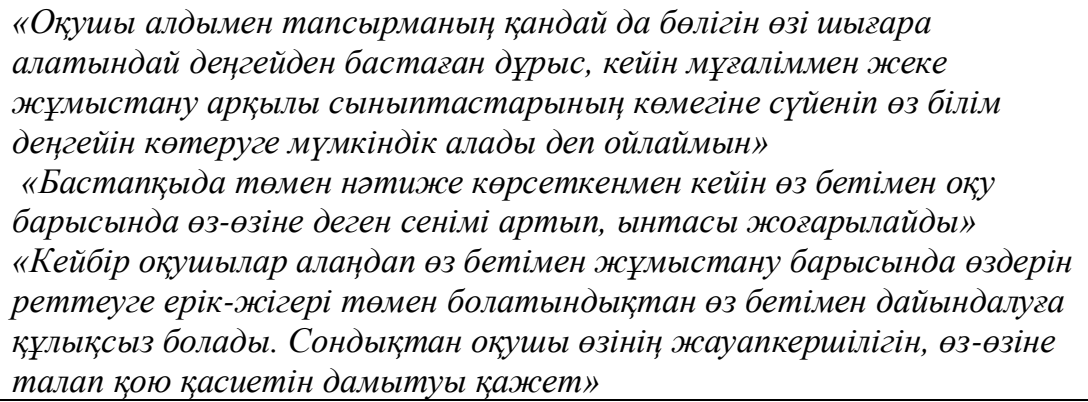 } \\
\hline 5 & $\begin{array}{l}\text { Өз бетімен жұмыстану } \\
\text { сәтті болу үшін қандай } \\
\text { алғышарттар қажет деп } \\
\text { ойлайсың? }\end{array}$ & \multicolumn{2}{|c|}{ 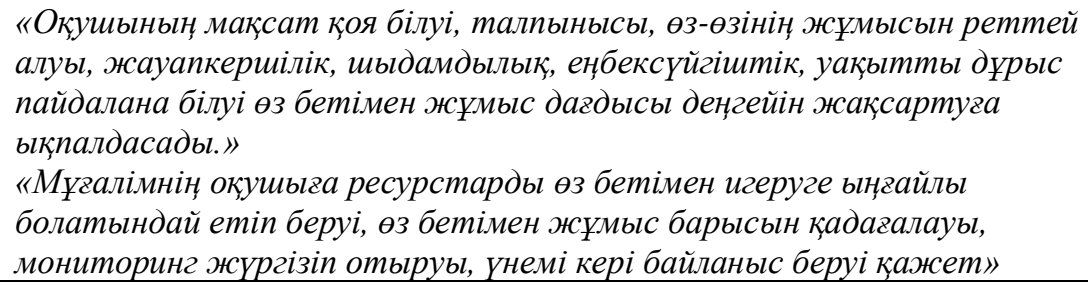 } \\
\hline
\end{tabular}




\section{III. Байқау сынағы мен қорытынды аттестаттау нәтижелеріне қатысты зерттеу нәтижелерін салыстыру және оларды талдау:}

Кесте 5.

\begin{tabular}{|c|c|}
\hline Байқау сынағы & \\
\hline \multicolumn{2}{|c|}{$\begin{array}{l}\text { Фактор 1: Оқушылардың өз бетімен жұмысқа жіберген уақыттары. } \\
\text { Окушылардың өз бетімен жұмысқа жіберген уақыттары мен байқау сынағы нәтижесіне әсерін } \\
\text { зерттеу барысында корреляциялық коэффициенті есептелді }\end{array}$} \\
\hline \begin{tabular}{l|l} 
Қорытынды $1:$ Корреляциялық коэффициент: & \\
0,$13 ;$ бұл екі фактордың арасында оң байланыс & \\
бар, бірақ шамалы, өйткені ол 0-ге жақын. \\
/Қосымша $1 /$
\end{tabular} & $\begin{array}{l}\text { Қорытынды } 1: \text { Корреляциялық коэффициент: } \\
0,10 \text {; бұл екі фактордың арасында оң } \\
\text { байланыс бар, бірақ шамалы, өйткені ол 0-ге } \\
\text { жақын. /Қосымша 1/ }\end{array}$ \\
\hline \multicolumn{2}{|c|}{$\begin{array}{l}\text { Фактор 2: Окушының жеке тұлғалық қасиеттері } \\
\text { Окушылардың жеке тұлғалық қасиеттерінің байқау сынағы нәтижелеріне әсерін білу } \\
\text { мақсатында әрбір оқушының барлық } 18 \text { қасиеттері бойынша орта мәні есептеліп } \\
\text { корреляциялық коэффициент анықталды. }\end{array}$} \\
\hline $\begin{array}{l}\text { Қорытынды2: Корреляциялық коэффициент: } 0,37 \text {; } \\
\text { бұл екі фактордың арасында оң(нашар) байланыс } \\
\text { бар екендігін көрсетеді./Қосымша 2/ }\end{array}$ & $\begin{array}{l}\text { Қорытынды2: Корреляциялық } \\
\text { коэффициент: 0,28; бұл екі фактордың } \\
\text { арасында оң(нашар) байланыс бар } \\
\text { екендігін көрсетеді./Қосымша 2/ }\end{array}$ \\
\hline \multicolumn{2}{|c|}{$\begin{array}{l}\text { Окушыларға өз бетімен жұмыс дағдысы деңгейлерін 0-10 баллдық есеппен бағалауларь } \\
\text { сұралып, алынған нәтижелерге корреляциялық талдау жасалды. }\end{array}$} \\
\hline $\begin{array}{l}\text { Қорытынды 3: Корреляциялық коэффициент: 0,6; } \\
\text { бұл екі фактордың арасында оң(жақсы) байланыс } \\
\text { бары көрінді. /Қосымша 3/ }\end{array}$ & $\begin{array}{l}\text { Қорытынды 3: Корреляциялық } \\
\text { коэффициент: 0,6; бұл екі фактордың } \\
\text { арасында оң(жақсы) байланыс бары } \\
\text { көрінді. /Қосымша 3/ }\end{array}$ \\
\hline
\end{tabular}

\section{Зерттеу нәтижелері.}

$\checkmark$ Өз бетімен оқытудың сәтті болуына «күнделік жүргізу» әдісінің ықпалының оң болғаны расталды;

$\checkmark$ Оқушылардың өз бетімен жұмысқа жіберген уақыттары мен байқау сынағы нәтижесіне әсерінің өте әлсіз екені көрінді.

Корреляция коэффициенті: 0,1

$\checkmark$ Окушылардың жеке тұлғалық қасиеттері мен қорытынды емтихан нәтижелерінің арасында оң(шамалы) байланыс бары анықталды. Корреляция коэффициенті: 0,3

$\checkmark$ Өз бетімен оқу дағдысының деңгейі мен қорытынды емтихан нәтижелерінің арасында оң(жақсы) байланыс бар екендігі анықталды. Корреляция коэффициенті:0,6

\section{IV. Қорытынды}

1. Мектеп бітірушілердің байқау сынақтары нәтижелеріне әсер етуші негізгі факторларөз бетімен оқу дағдысының деңгейі-64\%, жеке тұлғалық қасиеттері-34\%, құрайды ал қалғанын оқушыңың отбасы жағдайы, т.б әсер етуші факторлар болуы мүмкін.

2. Өз бетімен жұмысты тиімді әдістерінің бірі -күнделік жүргізу оң пікірінше тиімділігін көрсетті.

3. Зерттеу нәтижелерін одан әрі интерпретациялау және практикадағы салдарларды зерттеу үшін өзге пән бірлестіктері мұғалімдері қатысуымен конференция ұйымдастырылды. Сессиялық отырыста оқушылардың өзбетімен жұмысы дағдысын жоғарылату мәселесінің өзектілігі атап өтілді.

Сондай-ақ емтиханда қарастырылатын барлық материалды меңгеріп шығуға берілген сағат көлемі аздық ететіндіктен, оқушының өзбетімен жұмыстану деңгейінің төмендігі емтихан нәтижесіне кері әсер етуші фактор болып саналатындығы айтылды.

4. Бұл мәселені әрі қарай тереңірек зерттеу оқушылардың өзбетімен жұмысының сәтті болуына ықпалдасатын тиімді жолдарды табуға мүмкіндік береді. Сондықтан бұл зерттеу қорытындылары мұғалімдерге оқушылардың өзбетімен жұмысын ұйымдастыру барысында оқыту-әдістемелік кешендер дайындауда көмекші құрал ретінде ұсынылды. 


\section{ӘДЕБИЕТТЕР}

1. Қазақстан Республикасының Президенті Н.Ә.Назарбаев. «Қазақстан- 2050» стратегиясы: қалыптасқан мемлекеттің жаңа саяси бағыты»: Қазақстан халқына жолдауы // Егемен Қазақстан. 2012, желтоқсан - 14.

2. «Назарбаев Зияткерлік мектептері» дербес білім беру ұйымының 2030 жылға дейінгі даму стратегиясы

3. Определение значимых умений самостоятельной работы для успешного обучения в вузе / Г. В. Милованова [и др.] // Интеграция образования. 2017. Т. 21, № 2. С. 218-229.

4. Басин М. Формирование навыков волевой регуляции у девиантных подростков // Соц. педагогика, 2004.

5. Воспитание сознательной дисциплины и культуры поведения школьников: Из опыта работы / Сост. Ф.А. Бобков. - М.: Просвещение, 1982.

6. Кочетов А.И. Особенности самовоспитания подростков // Советская педагогика. 1966. №10. С. 36.

7. Тайчинов М.Г. Воспитание и самовоспитание школьников. М.:.Просвещение, 1982.

8. Брязгунов И., Касатикова Е. И что с ними делать? [Гиперактивность детей]. // Лучшие страницы пед. прессы - 2002 - N1.

9. Вайнер М.Э. Коррекция неконструктивного поведения школьников с помощью игры // Начальная школа - 2004.

10. Кривцова С.В. Учитель и проблемы дисциплины // Школьные технологии - 2005.

11. What is independent learning and what are the benefits for students? Bill Meyer, Naomi Haywood, Darshan Sachdev and Sally Faraday London: Department for Children, Schools and Families Research Report 051, 2008

12. Independent learning: student perspectives and experiences /Liz Thomas, Christine Hockings, James Ottaway and Robert Jones/

13. Kesten, Cyril, Independent Learning, Saskatchewan Department of Education Core Curriculum Investigation Project, 1987.

14. Barr, R. and J. Tagg. "From Teaching to Learning - A New Paradigm for Undergraduate Education." Change 27.6 (1995): 12-25. Available on-line at http://ilte.ius.edu/pdf/BarrTagg.pdf.

15. Little, D. (1996). Some steps in the Evolution of Theory and Practice. ERIC: FL024941

16. Usuki, M. (2001). From the Learners' Perspectives: The Needs for Awareness-Raising towards Autonomy and Roles of the Teachers. ERIC: FL026831

17. Candy, P. (1991) Self-direction for lifelong learning: a comprehensive guide to theory and practice. San Francisco: Jossey Bass

18. Crawford, A. "The Succeed Model for Independent Learning.", Available on-line at http://calvin.stemnet.nf.ca/ acrawfor/lrc2b.html

19. Saber, S. A., Crosling. G., \& Rahman. (nd). International students and independent learning: Towards an Eclectic Framework. Australia: Monash University.

20. Hubbard, R. S. (1994). How Effective Is Self-Directed Learning at Generating Successful Learning Experience, and What Is Its Role within Higher Education ERIC: FL022468 9. Kim, R., Olfman, L., Ryan, T., \& Eryilmaz, E. (2014). Leveraging a personalized system to improve self-directed learning in online educational environments. Computers \& Education, 70, 150-160.]

21. How to develop independent learners. M. Gershon. Tes Resources tes.com/teaching-resources Copyright Tes Global Ltd, - 2014

\section{ҚОСЫМША}

Kосыммиа 1

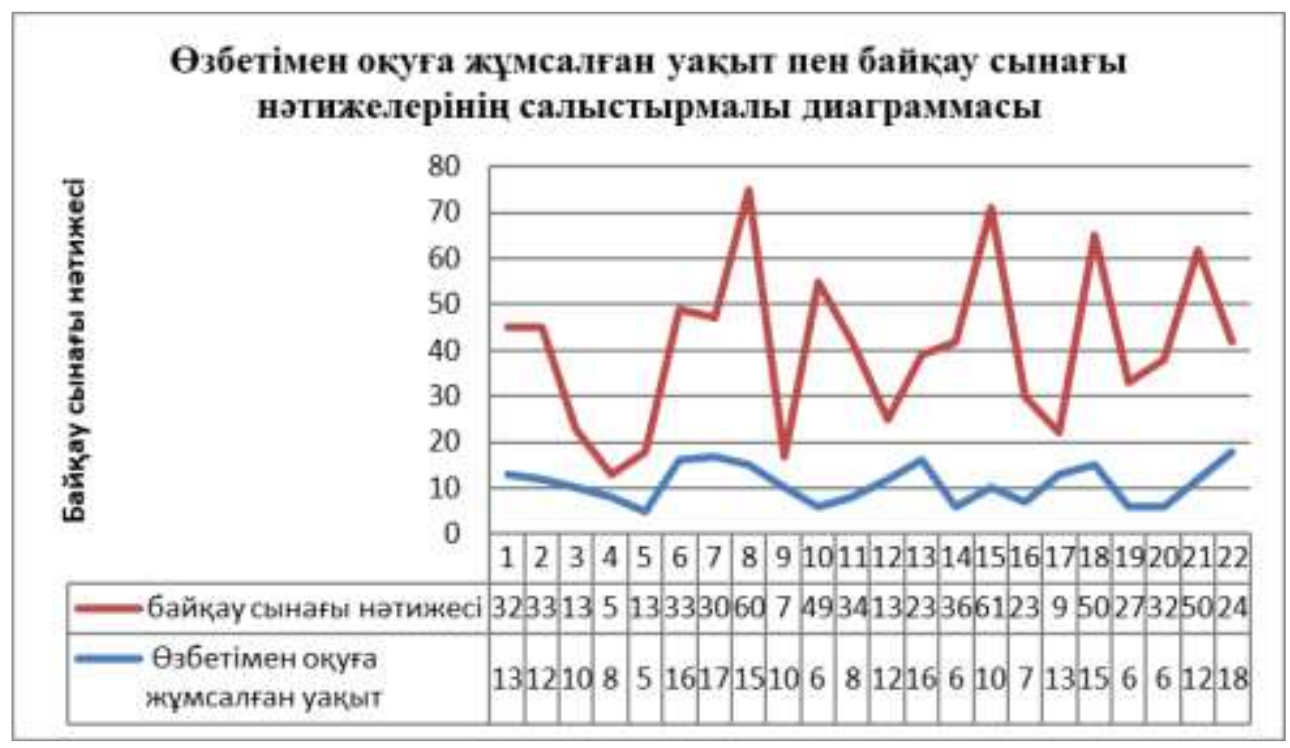


Kосыммиа 2
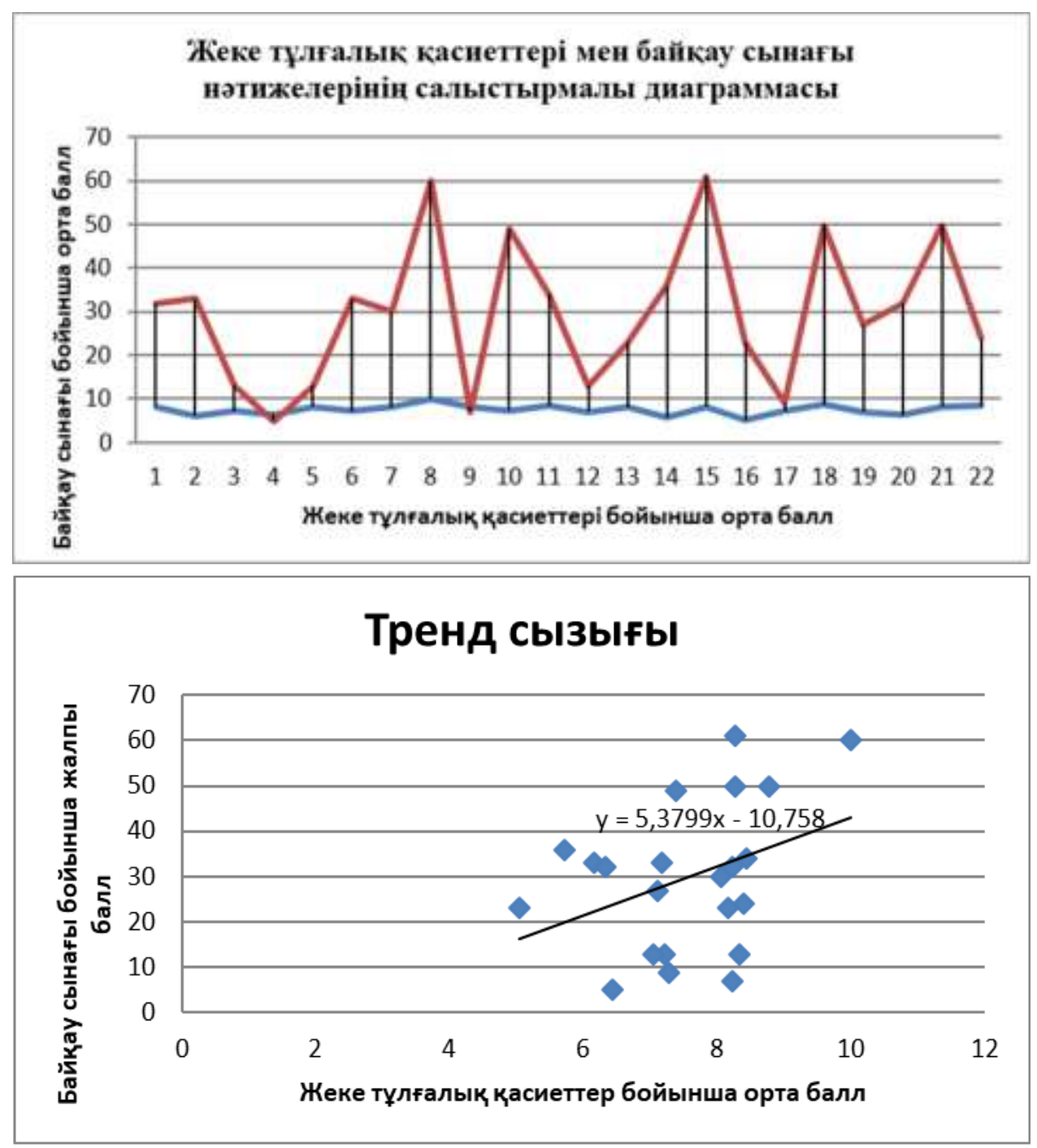

Kосыммиа 3

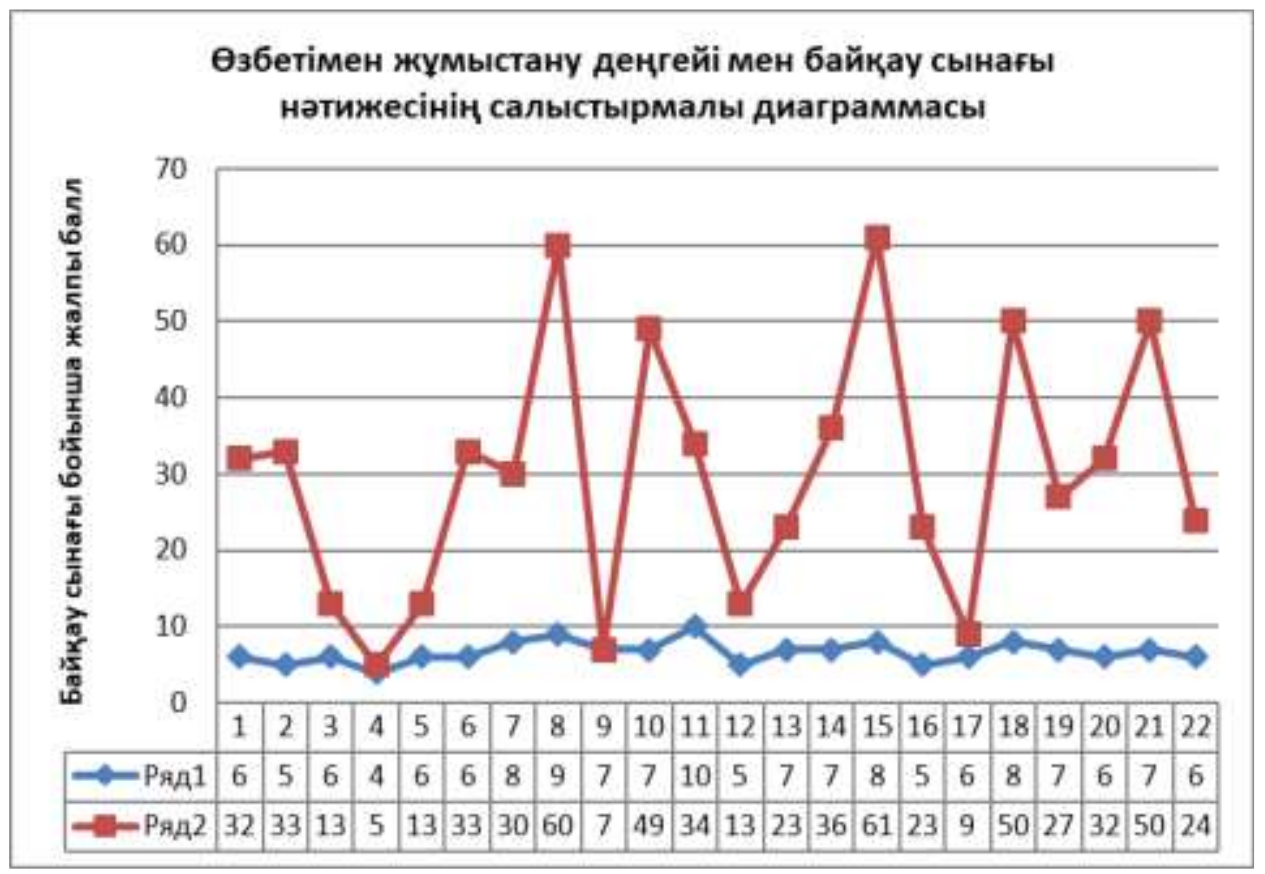




\section{тренд сызығы}

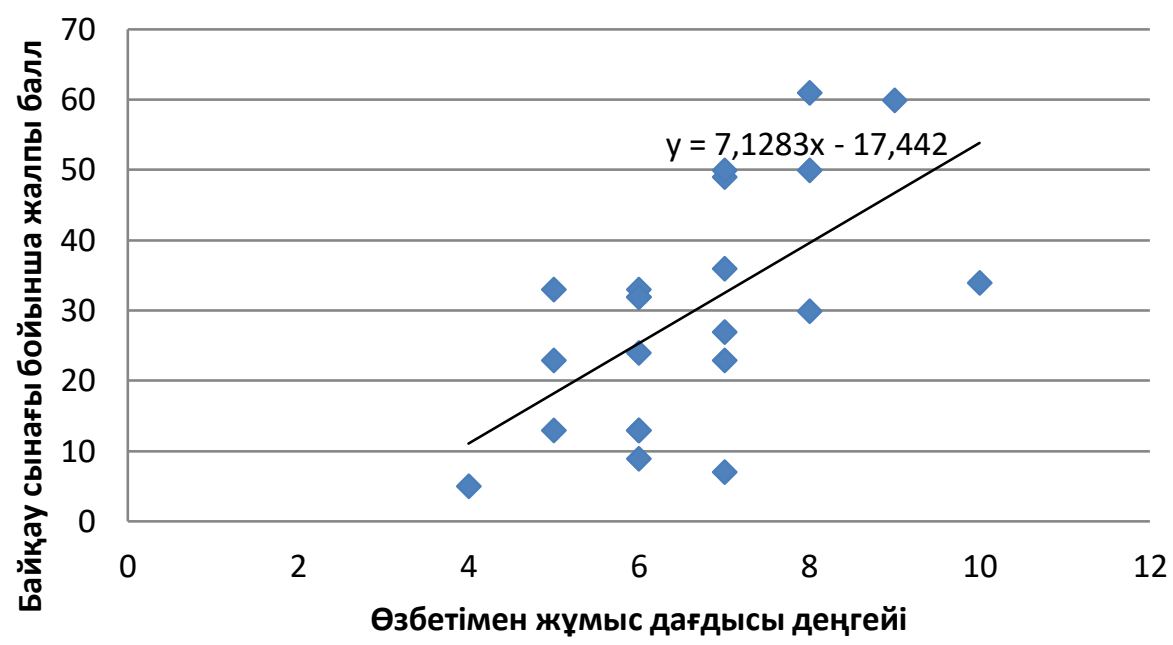

